HARVARD UNIVERSITY.

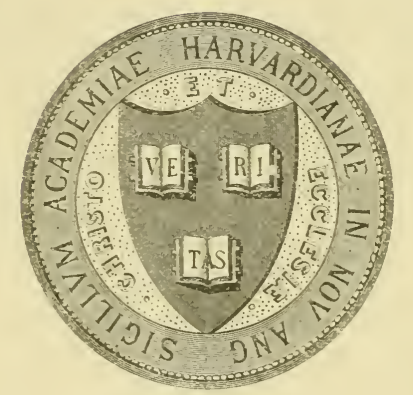

L I B R A R

(1) TII:

MUSEUM OF COMPARATIVE ZOÖLOGY.

18,745

the Editors of the Amerciane Vaturalist

Cetiver 28,1902 


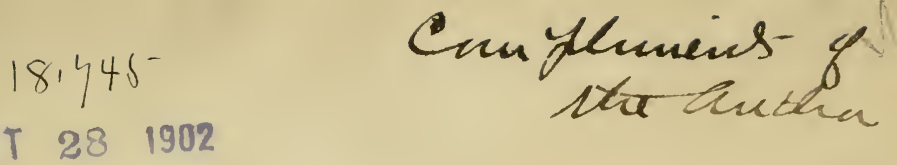

\title{
Preliminary Report upon the Introduction of the Eastern Oyster to the Oregon
}

\section{Coast; Summer of 1897.}

\author{
F. L. WASHBURN, A. M., \\ University of Oregon, Eugene, Oregon.
}

It is quite fitting that those interested in the success of this experiment should be informed of its present status, and be furnished with a report less detailed than that forwarded to Washington and yet more complete than the communication in the Oregonian of Jan. 1, 1898.

As is well known the work was authorized by the United States Fish Commission; it was in charge of the State University. The U.S. Government paid all the expenses, and it is some satisfaction to know that the experiment has cost the people of Oregon nothing.

Regarding the present condition of the oyster plant, it gives me pleasure to state that the condition of the introduced specimens leaves nothing further to be desired; they have withstood two winters successfully and have made phenomenal growth, far exceeding what they would have made in the same time in their native waters. Further, they spawned. A sufficiently complete statement regarding the work in artificial fertilization has been already made through the medium of the press; suffice it to say that many million of swimming oyster embryos were turned into the waters of Yaquina Bay. Up to the time of leaving the coast, Sept. 12, no spat (developed spawn) of Eastern oysters had been found. The writer hopes that better success will attend the search the coming season and that sufficient spat will be discovered in favorable localities to warrant declaring the experiment a success scientifically if not practically. From data given below regarding the sudden variability in the temperature and salinity of the water, it must be confessed that the developing spawn has to run a trying gauntlet before attaining the security afforded by a strong shell. It is too early, however, to judge regarding the success or failure of the experiment.

In the work of last summer very complete records of salinity and temperature at different tides and hours were obtained at Yaquina Bay, Coos Bay, Tillamook and Netarts. At Yaquina Bay, particularly, daily air temperature, and surface and bottom water temperature were obtained during the entire summer and a large part of the previous winter, Mr. Geo. King of Oyster City, 
acting as observer. 'l'o give all of the tables compiled from my individual work and the work of various observers would make this report unnecessarily voluminous. I will, however, introduce portions of tables to illustrate the two serious difficulties referred to above, viz: sudden variations in the salinity and temperature of the water resulting from the change of tide, strong winds from the ocean, etc. It is with the expectation of finding some locality, presumably at Yaquina Bay, which bay appears to offer the best advantages, where the spawn may not meet with such sudden changes, that the writer intends to continue and complete during the coming summer the work begun last season.

Oyster City, Yaquina Bay, seven and one-half miles from the ocean. $S$ denotos

\begin{tabular}{|c|c|c|c|c|c|}
\hline DATE. & TIME. & TIDE. & SALINITY. & TEMP. ${ }^{\circ} \mathrm{F}$. & OBSERVER. \\
\hline July 8 & $\mathrm{I} 2 \mathrm{~m}$ & Low. & I .oI45 S & 68 & F. L. W. \\
\hline July 9 & $8: 45$ a.m. & High. & $\mathrm{I} .021 \mathrm{~S}$ & 64 & $\therefore$ is \\
\hline & $10: 15 a . m$. & Ebb. & $1.0165 \mathrm{~S}$ & 68 & "6 \\
\hline & 12:30p.m. & Low. & $\begin{array}{l}\text { I.0165 S } \\
\text { I.018 B }\end{array}$ & $\begin{array}{l}68 \\
68\end{array}$ & ،6. \\
\hline July I4 & 9:30 a. m. & Low. & $\begin{array}{l}\text { I.OI5 } 1 / 2 \mathrm{~S} \\
\text { I.OI } 5^{1 / 2} \mathrm{~B}\end{array}$ & $\begin{array}{l}68 \\
68\end{array}$ & ، \\
\hline July 2 I & 8 a. $\mathrm{m}$. & $1 / 2 \mathrm{Ebb}$. & $1.02 \mathrm{I}$ & 64 & “ \\
\hline Aug. 6 & 9 a. $\mathrm{m}$. & & $\begin{array}{l}1.021 \mathrm{~S} \\
1.022 \mathrm{~B}\end{array}$ & $\begin{array}{l}63 \\
6 I\end{array}$ & “ \\
\hline
\end{tabular}

The above extract from table serves to show the average salinity at Oyster City during the summer ranging from 1.0145 to 1.022 . The average density of ncean water on our coast during the summer was found to be 1.025 at $50^{\circ}$ Cent.

From a series of olsservation on water temperature (George King, Ohserver), from June 28th to Aug. 3rd, the dates July 14, $15,16,17,18$ and 19 are here represented to show the sudden. changes likely to occur during the spawning season.

Oyster City; near planted oysters. S' denotes surface, B, Bottom.

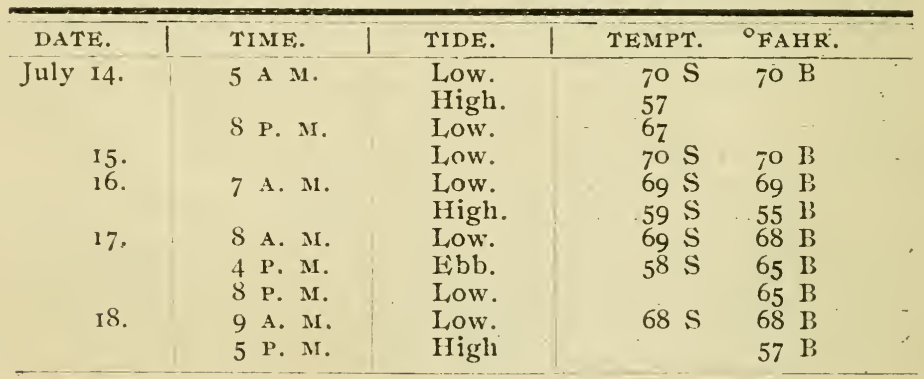


The following extracts from tables compiled from work done at Coos, Tillamook and Netarts Bays in Oregon, and at Humboldt Bay, Calif., give a very good idea of the conditions prevailing at each place. Eastern oysters were planted in the latter locality in November, 1896 , contemporaneously with those planted at Yaquina Bay.

Coos Bay.

\begin{tabular}{|c|c|c|c|c|c|c|}
\hline LOCALITY. & DATE. & TIME. & TIDE. & $\begin{array}{l}\text { SALIN- } \\
\text { ITY. }\end{array}$ & $\begin{array}{c}\text { TEMP. } \\
{ }^{\circ} \mathrm{F} .\end{array}$ & $\begin{array}{c}\text { OB- } \\
\text { SERV'R }\end{array}$ \\
\hline Empire City. & Aug. Io. & $\begin{array}{c}8: 30 \text { a. m } \\
\text { I0:45 a. m }\end{array}$ & $\begin{array}{l}2 / 3 \mathrm{Fl} . \\
\text { High. }\end{array}$ & $\begin{array}{l}1.021 \mathrm{~S} \\
1.023 \mathrm{~S}\end{array}$ & 63 & F.L.W. \\
\hline Marshfield. & “ & 4 p. m & $2 / 3 \mathrm{Ebb}$ & $\begin{array}{l}\text { I.018 S } \\
\text { I.0I8 2-5 B }\end{array}$ & $\begin{array}{l}64 \\
67\end{array}$ & " \\
\hline & Aug. II. & $8: \mathrm{I} 5 \mathrm{a}, \mathrm{m}$ & Low. & $\begin{array}{l}\text { I.OI5 S } \\
\text { I.OI5 B }\end{array}$ & $\begin{array}{l}67 \\
68\end{array}$ & “" \\
\hline $\begin{array}{l}\text { Empire City. } \\
\text { Glasow. }\end{array}$ & $\begin{array}{ll}\text { “ } & \text { I } 2 . \\
\text { “. } & \text { I2. }\end{array}$ & $\begin{array}{l}7 \text { a.m } \\
\text { IO a. m, }\end{array}$ & $\begin{array}{l}3 / 4 \mathrm{Ebb} . \\
1 / 3 \mathrm{Fl} .\end{array}$ & 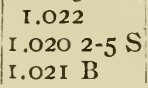 & $\begin{array}{l}59 \\
67 \\
67\end{array}$ & " \\
\hline
\end{tabular}

It will be noted from this table that except at Marshfield the water approaches in saltness that of the ocean.

Tillamook Bay.

\begin{tabular}{|c|c|c|c|c|c|}
\hline LOCALITY. & TIME. & TIDE. & SALINITY. & TEMP. ${ }^{\circ} \mathrm{F}$ & OBS'R. \\
\hline $\begin{array}{l}\text { Mth. of Tillamook } \\
\text { \& Trask.Rivers... }\end{array}$ & 9:30 a.m. & 1/3 Full. & I.008 S & 63 & F.I.W. \\
\hline Hobsonville........ & I I:25a.m. & $2 / 3$ Full. & I.025 S & 44 & ، \\
\hline Garibaldi.... & I2:30p.m & High. & I. $0243-5 \mathrm{~S}$ & $\begin{array}{l}44 \\
44\end{array}$ & 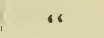 \\
\hline
\end{tabular}

Extremely salt and cold except at extreme head of bay, where mud and fresh water would kill oysters in winter season.

Netarts Bay.

\begin{tabular}{c|c|c|c|c|c}
\hline LOCALITY. & TIME. & TIDE. & SALINITY. & TEMP. ${ }^{\circ}$ F. & OBS'R. \\
Head of Bay... & $8:$ I5 a.m. & Low. & I.024 & 59 & F. L. W. \\
". & $8: 45$ a.m. Ext. Low & I.025 & 59 & "Ex \\
\hline
\end{tabular}

Although the Netarts Bay Oyster is the same species (Ostrea. lurida) as that found at Yaquina Bay, the extreme saltiness of the water of this bay gives it a characteristic salty taste, much prized ly some. 
Humboldt Bay, California.

\begin{tabular}{|c|c|c|c|c|c|}
\hline LOCALITY & TIME. & TIDE. & SALINITY. & TEMP. ${ }^{\circ} \mathrm{F}$. & OBS'R. \\
\hline $\begin{array}{l}\text { Samoa ........ } \\
\text { Beacon } 8 \ldots \ldots \\
\text { Eureka........ }\end{array}$ & $\begin{array}{l}\text { 10:30a.m. } \\
\text { 10:45a.m. } \\
\text { 2:30 p.m. }\end{array}$ & $\begin{array}{l}\text { Flood. } \\
\text { Flood. } \\
\text { High. }\end{array}$ & 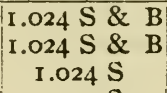 & $\begin{array}{c}6 \text { I } \mathrm{S} \& \mathrm{~B} \\
63 \mathrm{~S} \& \mathrm{~B} \\
60\end{array}$ & $\begin{array}{c}\text { F. L. W. } \\
\text { ، }\end{array}$ \\
\hline $\begin{array}{l}\text { Beacon } 8 . . . . \\
\text { Frshwtr Slough } \\
\text { nr. Hayne's.. }\end{array}$ & 3:15 p. m. & High. & \begin{tabular}{|c|}
$1.024 \mathrm{~S}$ \\
$1.024 \mathrm{I}-5 \mathrm{~B}$ \\
$1.023 \mathrm{I}-5 \mathrm{~S}$
\end{tabular} & $\begin{array}{l}57 \\
55 \\
63\end{array}$ & 66 \\
\hline
\end{tabular}

The optimum spawning temperature on the Atlantic coast is between $70^{\circ}$ and $80^{\circ} \mathrm{F}$. and the salinity may be as low as 1.012 . In the most northern locality, however, where the eastern oyster is found, the spawn developes in much colder water.

Places can be found in Yaquina Bay where a summer density of 1.012 with some variations can be secured. But such places are so far up the bay that the winter freshets might possibly endanger the lives of the oysters planted there.

As stated above Yaquina Bay appears to offer the greatest inducements. Coos Bay is somewhat cold and salt except near Marshfield at which place the oyster might suffer from winter freshets and sewage. At Glasgow, some miles below Marshfield a most excellent bottom for oysters was discovered, and if a cold water variety, from the neighborhood of New Branswick for instance, could be planted there, they night possibly prosper. Tillamook Bay is too cold and too sult except so far toward the head of the bay that oysters would be killed by mud and fresh water in the winter if placed there.

Humboldt Bay, Cal., visited by direction of the Fish Commissioner, was found to be unfavorable and the plant at that place was in poor condition.

It is clained on the best authority that Eastern oysters in San Francisco Bay have spawned and the spawn has developed, for some years. The two large companies controlling the Easteru oyster industry there deny this, although photographs to prove the assertion were secured some years ago by C. H. Townsend of the U.S. Fish Commission.

Biological Laboratory, A pril 21, 1898. 


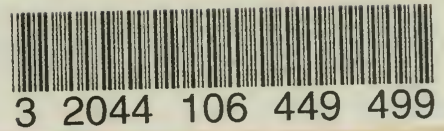




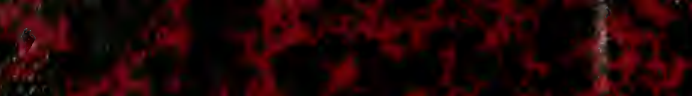

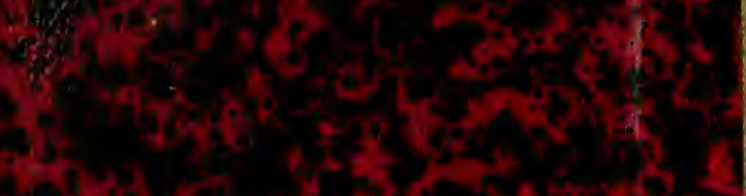

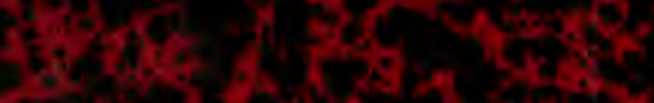
sinesosing

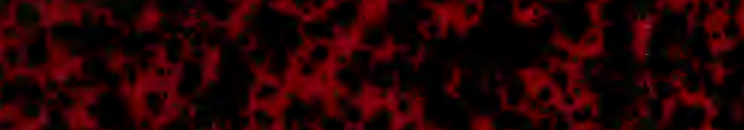
20.5. Finsthing

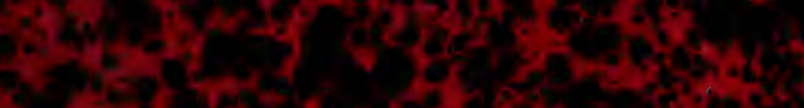

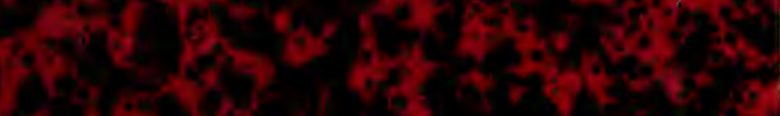
56.

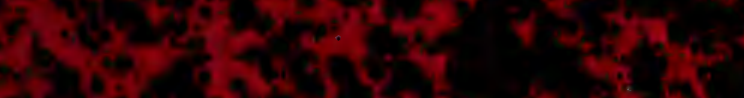

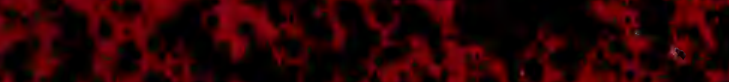

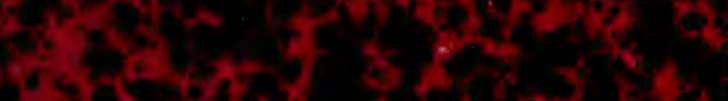

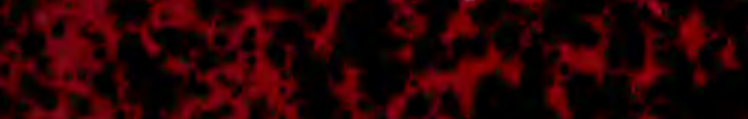
Matseracts

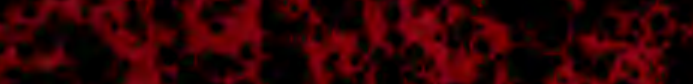

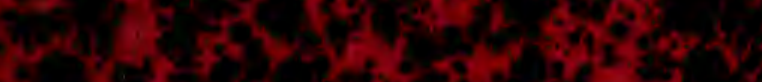
5. The

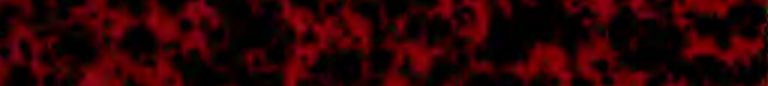

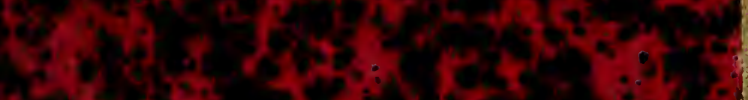

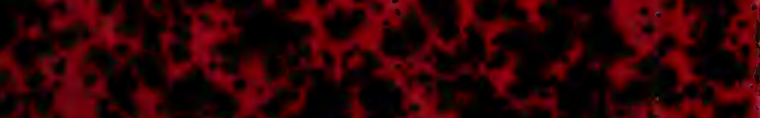

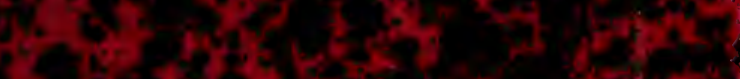
Nos and of

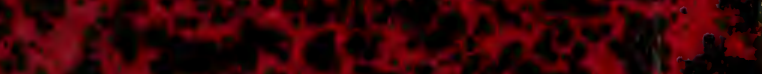

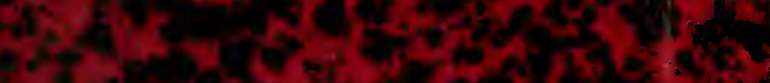
$3 x^{2}+3=0$

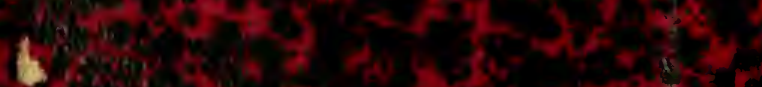

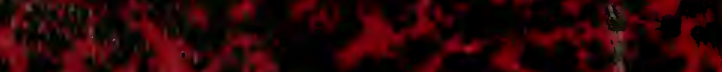

